\title{
UNIVERSITYOF
}

FORWARD

THINKING

WESTMINSTER用

WestminsterResearch

http://www.westminster.ac.uk/westminsterresearch

\section{Women Asylum Seekers in the Current Crisis: A Conversation}

Samuels, $\mathbf{H}$.

This is the published version of Samuels, H. (2017) Women Asylum Seekers in the Current Crisis: A Conversation. Feminist Legal Studies DOI: 10.1007/s10691-017-9346$Z$.

(C) The Author(s) 2017. This article is published with open access at Springerlink.com

The WestminsterResearch online digital archive at the University of Westminster aims to make the research output of the University available to a wider audience. Copyright and Moral Rights remain with the authors and/or copyright owners.

Whilst further distribution of specific materials from within this archive is forbidden, you may freely distribute the URL of WestminsterResearch: ((http://westminsterresearch.wmin.ac.uk/)).

In case of abuse or copyright appearing without permission e-mail repository@westminster.ac.uk 


\title{
Women Asylum Seekers in the Current Crisis: A Conversation
}

\author{
Harriet Samuels 1
}

(C) Springer Science+Business Media Dordrecht 2017

\begin{abstract}
To mark International Women's Day the Research Group for Law, Gender and Sexuality at Westminster Law School held an evening conversation on 10 March 2016 on Women and Asylum. Speakers working in different areas of the asylum system shared their insights and experiences with an audience of staff, students, activists and other visitors. Harriet Samuels (Westminster Law School) chaired the conversation and the speakers were Princess Chine Onyeukwu (The Protection Gap Campaign), Debora Singer (Policy and Research Manager, Asylum Aid), Priya Solanki (Barrister, 1 Pump Court Chambers) and Zoe Harper (Legal Officer, Immigration Law Practitioners' Association). This article is an edited extract from the transcript of the presentations and wide-ranging discussion, including the question and answer session. The discussion focused on the different steps in the refugee determination process and considered, in particular, the gendering of credibility and how women's perceived lack of credibility has a significant impact on determinations and processes.
\end{abstract}

Keywords Gender · Asylum · Women · Refugee · Immigration · Credibility

\section{Introduction}

International Women's Day is a time to reflect on the state of the world's women. It is an opportunity to show solidarity, make common cause with other feminists around the world and to celebrate achievements. Women's Day attracts media interest and is a chance to expose the many violations of women's rights. In 2016 the Research Group for Law, Gender and Sexuality chose the issue of Women and

Harriet Samuels

H.Samuels@westminster.ac.uk

1 Westminster Law School, University of Westminster, London, UK 
Asylum for an evening conversation at the University of Westminster, London in the hope that it would generate discussion about the asylum system in the United Kingdom (UK). ${ }^{1}$ The difficult and hostile atmosphere in the UK around immigration had intensified in recent years with the rise of the United Kingdom Independence Party (UKIP), the government introduction of an immigration cap for non-European Union migrants, and yet more stringent policies and legislation around family reunion (Dennison and Goodwin 2015; Barnden 2013). The openly hostile atmosphere became particularly obvious when, in 2012, the Home Office thought it acceptable to experiment by using vans with large billboards to travel around six London boroughs. The billboards proclaimed: "Go home or face arrest" as part of a campaign to target "illegal immigrants". Critics accused the government of using the language of the racist National Front. The billboard vans were discontinued, not because they were deemed offensive, but because they were found to be ineffective and used misleading statistics. ${ }^{2}$

Asylum seekers and refugees form a subgroup of migrants with their claims being determined in accordance with the Refugee Convention of 1951 and the 1967 protocol. ${ }^{3}$ During the spring of 2016 there was concern that Europe was in the midst of a crisis with asylum seekers leaving troubled areas and conflict in the Middle East, particularly Syria, Iraq and Afghanistan. The United Nations High Commissioner for Refugees (UNHCR) stated that: "In 2015, and the first months of 2016, almost 1.2 million refugees and migrants reached European shores, most fleeing conflict and persecution. Many lost their lives or saw loved ones perished at sea in their attempt to reach safety. An increasing number of families, women, and unaccompanied children undertook perilous journeys across several countries and often faced exploitation at the hands of smugglers" (UNHCR 2016).

Outrage was expressed in the press in September 2015 at the picture of a lifeless toddler. The little boy was one of twelve Syrians trying to reach Europe who had drowned, and whose body was washed up on a Turkish beach (BBC 2015). Nevertheless, mainstream politicians regularly used intemperate language, which contributed to the ongoing othering of migrants. The campaign to hold a referendum in June 2016 on whether the United Kingdom should leave the European Union, made matters worse.

This was the climate in which the conversation around women and asylum occurred. All of our speakers gave their talks against this backdrop, but went on to speak more specifically about the gendered dimensions of the asylum process in the UK. There is a clearly gendered aspect to immigration policy with the detention of

\footnotetext{
1 The full recording of the event is available free to watch at https://www.youtube.com/watch? $\mathrm{v}=$ 8m4GtSCt5fI. Accessed 10 September 2016.

2 See Advertising Standard Authority, Ruling on Home Office (complaint reference A13-237331), 9 October 2013; available at https://www.asa.org.uk/Rulings/Adjudications/2013/10/Home-Office/SHP_ ADJ_237331.aspx\#.V-X6CMrJz8. Accessed 1 October 2016.

3 United Nations, General Assembly, Geneva Convention Relating to the Status of Refugees, 189

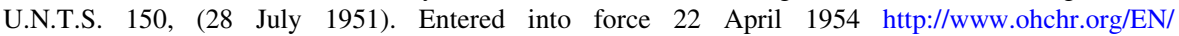
ProfessionalInterest/Pages/StatusOfRefugees.aspx. Accessed 25 January 2017. See also United Nations, General Assembly, Protocol Relating to the Status of Refugees, 606 U.N.T.S. 267 (31 January 1967). Entered into force 4 October 1967 https://reaties.un.org/doc/Publication/MTDSG/Volume\%20I/ Chapter\%20V/V-5.en.pdf. Accessed 25 January 2017.
} 
women migrants at Yarl's Wood detention centre causing concern (Townsend 2015). Laws targeting problems of forced marriage often may be used as a tool of immigration control (Women for Refugee Women 2015).

Feminists have campaigned for some time to ensure that the interests of women and girls are accounted for in the asylum process (Edwards 2010). The UNHCR has mainstreamed the need to consider the different impact of flight on men, women and children, but the implementation is far from ideal. The Refugee Convention 1951 does not specifically provide for refugee status based on gender persecution. It is only through the development of case law that the interpretation and application of the Convention has come to recognise violence against women, for example, as a form of recognised persecution. ${ }^{4}$ There are also guidelines to ensure that officials making refugee determinations consider women's claims in a gender sensitive manner (UNHCR 2002a, b, 2008).

During the conversation on Women and Asylum we heard a personal account of what it is like to go through the asylum process from Princess Chine Onyeukwu. At a gathering discussing law, policies and processes, it is important to be reminded of the people at the centre of the system. Princess recounted the absurdity of being forced to make asylum claims on the phone to the Home Office when the lines are constantly busy and phone calls are expensive. She explained the difficulty of being repeatedly asked the same question at interview, and of having to relate personal and difficult experiences to sceptical officials who did not seem to understand the effects of post-traumatic stress disorder.

Our other speakers all highlighted the problems that women have with the refugee determination process. Debora Singer from Asylum Aid gave us an account of her work on The Protection Gap Campaign. Research had shown women's asylum claims were often rejected at the initial stages because of a lack of credibility. Asylum Aid concluded that this was because it was hard for women to provide the evidence for persecution that had often occurred in private. The Protection Gap campaign therefore targets the manner in which asylum interviews are conducted and includes demands for an interview process that respects the trauma that has been endured and puts forward practical solutions such as providing childcare. Priya Solanka, a barrister who works on immigration and asylum law, described some of the cases that she had worked on in the tribunal system. She highlighted the problems encountered by those who had endured traumas such as domestic violence, rape and sexual assault. These included the difficulties in getting permission for an all female court, failing to consider the woman's asylum claim individually and instead subsuming it into that of her husband, and the lack of gender-specific guidelines. Our last speaker Zoe Harper from the Immigration Law Practitioners' Association talked about the importance of obtaining sound legal advice to guide women through the process. She took the conversation to the migrant camps in Calais in discussing the dangers for asylum seekers coming to the UK and the lack of opportunities to claim asylum from abroad.

\footnotetext{
${ }^{4}$ Islam v. Secretary of State for the Home Department and R. v. Immigration Appeal Tribunal and Secretary of State for the Home Department, ex parte Shah (Islam and Shah) [1999] 2 WLR 1015 and Fornah v. Secretary of State for the Home Department [2006] UKHL 46.
} 
International Women's Day gave us the opportunity to discuss the asylum process. Our speakers were attentive to the specific nuances of the refugee determination process for women that can make the difference between being granted refugee status or being removed from the UK. Several of the speakers referred to the international treaties, agreements and policies that are supposed to ensure that the needs of women asylum seekers are met. As participants and practitioners they were able to provide us with insights and observations about how the system works in practice. The questions from the audience concerned how to improve gender sensitivity, including whether all-female tribunals were beneficial, and seeking clarification on the number of female judges in tribunals. They asked how the Home Office could be persuaded to adopt the procedures and protections given to victims of sexual abuse and violence in domestic law, when they are responding to asylum seekers who have suffered similar traumas in their own country?

In sum, the presentations gave those attending a sometimes depressing and distressing on-the-ground view. Yet the speakers also did valuable work in energising the audience of students, staff and voluntary sector workers in reminding us of the importance of legal and political activism.

\section{Conversation}

Harriet Samuels, Reader in Law, University of Westminster (chair): Welcome everybody to the Westminster Law School, to the Research Group for Law, Gender and Sexuality, and to this evening's conversation on Women and Asylum in the Current Context. We usually have an annual event, often around the time of International Women's Day, and the issues around Women and Asylum were particularly topical. I'd like to welcome our speakers who I'll introduce in a moment. Each speaker is going to talk for about 10-15 min, and then we will identify some common themes and open it up to the audience for questions and what we hope will be a great discussion.

\section{Princess Chine Onyeukwu and the Protection Gap Campaign}

My name is Princess or Chine. If you have a problem with 'Princess', it's not a title; it's my name. I am a lawyer by profession and have been involved with activism. I am involved currently with Asylum Aid's Protection Gap Campaign, ${ }^{5}$ which I am sure you will hear a bit more about. The question that everyone should ask is why do people seek asylum? Asylum, as you all know, is about seeking protection and refuge. Why do people, especially women, seek asylum? I am sure you all know many of the reasons. There is the issue of war. We all know what is happening in the Middle East and in all of the world; what has happened in the past and how women and children get the roughest end of the stick when these things happen. Mainly

\footnotetext{
${ }_{5}^{5}$ For more information see Asylum Aid, "The Protection Gap Campaign" http://www.asylumaid.org.uk/ protectiongap/. Accessed 10 September 2016.
} 
women suffer all kinds of atrocities and they flee. Some women are being forced into prostitution by traffickers, human traffickers. Women may come from societies that have very terrible widowhood practices. And then some of those women are young girls abused at home, or women abused in the case of war by soldiers, women who are beaten up and exposed to all manner of atrocities. And then, if we narrow it down a bit, there are some women who go through domestic violence. In some societies, domestic violence is really not looked at as anything. For some of these women, it's frowned upon to talk about being beaten up by your husband or your partner. Your own mother could tell you to just go back to him.

There are many reasons why a woman can no long bear it, and some of these women just have to take flight. It could be just flight within where they live, or not too far from where they live. Maybe they don't have money or anything and they cannot go far. They might relocate to another part of their country. But mainly we are thinking of women that left their country to seek refuge and come to a strange country. These women who are already traumatised women, who have flashbacks and so many emotions, who may have witnessed family members being killed and all manner of atrocities, or who have gone through domestic violence over so many years. These women come over here and for some obvious reasons they are looking for protection; they are looking for a place of safety. And nobody, you know, would blame any woman who has gone through such a rough, traumatic experience. It's a normal human instinct to flee when certain things are just too much for you. If you have seen all your family members killed, and you are able to escape, you would keep running to safety, you wouldn't just say, "Okay, you kill me as well!" Most times these people don't even kill you, they want to torture you and make you watch what they are doing. They just don't kill everybody; they leave some people to live with that. These women come over to a country like the UK and they claim asylum.

Like I used to say, each time I say it I don't know why people laugh, but one thing I know is that a lot of people agree with me when I say it, even for the ones that are dubbed "economic migrants" they are also running from poverty. If you ask me, everyone is entitled to run from a bad life and to want a better life. I don't see anything wrong with that but it is looked at as economic migration.

So you come over to this country and you claim asylum. Even claiming asylum is traumatic. The Home Office will not listen to anybody except if you call their office on the phone to claim asylum, or if you claim at the point of entry. So many people are so confused about what they have to do. My experience with many people, and my own personal experience, is that so many of these traumatised women are not even in the right frame of mind to claim at the point of entry. They are always very confused, they are always very scared, they are always very traumatised about even seeing uniforms. They have the history, they have something behind them, and this is what they are running away from. So initially, they don't claim at the point of entry. The way the Home Office interprets it is: "Why didn't you claim at the point of entry..." without asking "what made this woman not claim at the point of entry?" I think that these are the issues that they need to really, really consider and say: if this woman is not okay mentally then of course she should wait until she is ready. It's just like a woman disclosing sexual violence. With these disclosures you 
have to be ready. You don't just come and see the person you meet and spill your life history out to them, especially when you are traumatised.

You go through this harrowing experience, you have to call the Home Office number, endless times, for months. I remember what my solicitor said to me when I said: "I give up, I can't do it anymore." She said: "I'm afraid that's the only way." I went to Croydon, to the Home Office, and everybody said, "You went there?" I said, "Why not?" I believe I have a good reason to come here. I had a good job, I had a good career, I had good businesses, I had a house and a good car, I had a loving family and everything. If I come, there must be a reason, so they have to listen to it. Twice I went there, the majority of the people are scared of going, but I did, I went, and they said, the first time, "sorry, it must be on the phone." Imagine! "It must be on the phone!" And I said, "Look I'm here already, how about just giving me the forms." They said, "Sorry, it's over the phone." And I went. I tried for almost another month, I couldn't get through, and I went back again. This time I asked to see the supervisor. I thought: "If I see the supervisor maybe, just maybe she will understand. Maybe she will think that this woman has been twice, and of course if others are running away then somebody who is there is really not running from anything and maybe she has a cogent reason for claiming asylum." And she got a paper and just wrote: "She was here," something like that "she was here and started..." She said: "Okay, you go, but you have to keep trying on the phone."

It is very difficult even to get an appointment to go to Croydon. Don't forget that these lines are very expensive phone lines, for somebody who may not have money, who is not working. Even if you have money the money is running down fast. You know, you spend so much on these phone calls, and the frustrating thing is that you don't even get through. You do it for so long, and you are expected to do it, that's the only way. The only way to avoid this is if you claim at the point of entry.

When you now go for the interview proper... That is the most traumatizing thing I have ever done in my life, and that goes for everybody. If you are educated, it's a disadvantage to you. If you can speak good English and can express yourself it's a disadvantage because they see you as somebody who is intelligent and then you are coming here to do something. I don't know what. The kind of questions they ask you, and then the way they look at you, the way they address you. The same question is repeated a thousand times and it's really, really, really very traumatizing. And the tone of voice. The point is that this is not right for anybody. But we are saying that for women who must have gone through all of this, certain things should be taken into consideration when dealing with them.

With these women, when you expect that the woman is traumatised already, panicky, scared. Of course she forgets dates, of course she starts mixing up dates. Clients that I have worked with, they want to disclose certain things, but they are talking to a man. You can't disclose to somebody who has no sympathy, no empathy at all. In those circumstances you can't disclose anything, and then of course maybe what the woman is not disclosing is what is very vital to her asylum claim. This happens every day and is still happening.

Luckily, I got involved in the course of my work with some charitable organisations, got connected with Asylum Aid. I am so, so grateful for being involved with that organisation and what they are doing, especially the Protection Gap 
Campaign, which is a campaign to treat women better. If the women have children, the organisation can look after the children while they go through the initial interview. At least their children don't have to hear how many soldiers raped them or how many times they were beaten or sliced or some other horror, or how many times they were forced to sleep with so many men. There are some things that other people shouldn't even hear, apart from those that understand it. They should be able to choose if they want to speak to a female, if they feel more comfortable with a female officer, why not? It's an option, if they feel they can say more to a fellow female, they should be granted that. It's not too much to ask, because there are certain things you really cannot say to a man, especially when it affects you, especially in sexual things. And so many other things like that.

Asylum Aid is advocating for these things to change. These things are changing. There is light at the end of the tunnel. I got involved in activism because I just don't want other people to go through what I have gone through. Some of the damage that I went through when I claimed asylum, and throughout that period, I am still suffering from now. That happens to a lot of other women. The damage is almost permanent.

So I just feel if there is anything I can do to change this course of events I will keep doing it. That means speaking and informing and educating other young women to understand, to look at asylum seekers and refugees not just as people that came to take over your country or take over your jobs. These are not the issues. Some of these women have a lot of history behind them and you have to have a bit of empathy and understand that there must be a reason why some of them, if not all of them, come to the UK. I am advocating at the Home Office too and will not stop until they change.

We are advocating that the Home Office should do their work with a human face. If you have to interview somebody, just do your work. In doing your work you don't have to take that person as an economic migrant or send that person back, you have to treat that person right, especially for women. Thank you.

[Applause]

\section{Debora Singer, Policy and Research Manager, Asylum Aid}

I'm Debora Singer. I'm the Policy and Research Manager at Asylum Aid, and I run the women's project there. At Asylum Aid we provide legal representation to people claiming asylum, and we campaign particularly on the rights of women and try to improve the asylum system. I'm sure as all of us do our presentations you'll see the particular difficulties and barriers that women face during the asylum process.

Princess has spoken eloquently about the huge irony that women are fleeing all sorts of difficult things, and yet when they come to the UK, to seek protection, they end up going through a process here that's really traumatizing. What I wanted to do was to switch the mood slightly, and talk about how we try to persuade the Home Office to behave differently so as to improve the system for women who seek asylum in the UK.

I'm going to be talking about our campaign, the Protection Gap campaign, and the issue of credibility assessment and how that links up with our campaign. The 
campaign involves the 360 organisations that support the Charter of Rights of Women Seeking Asylum, which we run from Asylum Aid. I'll be going through the barriers that women face in the asylum process, but I'm going to start with the very practical things, which the Protection Gap campaign is asking for and which Princess has already alluded to.

The Protection Gap Campaign states that we believe that no woman seeking asylum should have to tell her story:

- in front of her children

- to a male interviewer or interpreter if she is not comfortable with this

- to someone who doesn't understand how trauma affects memory

- without being given counselling

- without information about her rights as a woman in the asylum system

Those of you who have experience of working in criminal justice or on sexual violence will know that women who have experienced sexual violence, rape or domestic violence will in general find it easier to disclose to another woman. I used to work at Victim Support and we knew that there. When I started at Asylum Aid about ten years ago and started saying, "maybe the Home Office should know this too," I just got these really blank faces. But gradually we did persuade them of the importance of having female interviewers and interpreters. But women don't always have female interviewers because when they are asked what they want they don't always realize the significance. Most women don't come from countries where they're asked what sort of official they want. Whereas we might be used in this country to being asked if you want a female GP. So when women are asked they don't see the importance of the question. They don't think: "Gosh, later on I'm going to have to be talking about all these really sensitive things and actually I'd rather speak to a woman." So the process needs to be improved.

Princess mentioned childcare. You can imagine what this meeting would be like now if we had a few 2 and 3-year-olds running around and a few teenagers being stroppy. Really we're talking about the little children though, because the older children will be at school. At the moment, following a campaign that we ran, there is childcare in a number of the Home Office offices. So when you go for your interview, if you're a single parent, you can take your children to a supervised playroom. You can have your interview without the distraction of children and without, as Princess said, the worry of traumatizing your children. As Princess said, things are moving because of this campaign. The Home Office are on their way to getting childcare provided, in every office where they conduct asylum interviews, in the next few months. So we're really getting somewhere with this one.

My next point is about the asylum interview. I've heard of cases where interviewers and interpreters don't understand things like female genital mutilation. They often get muddled between what's a forced marriage and what's an arranged marriage. So it's important that people are trained and that they understand. Also interviewers need to understand how memory is affected by trauma, and that narratives are not necessarily going to be told in a completely straightforward and coherent way. 
The Protection Gap campaign also stresses the importance of counselling. You've heard from Princess the sorts of harms that women have gone through that have made them come to the UK. I think most women would benefit from counselling in those circumstances. We're actually getting a long way at the moment with the Home Office and women are actually being referred for counselling.

We are also stressing the need for people to be provided with information so that they understand the asylum process. They need to know what their rights are in relation to things like childcare and female interviewers. They also need to understand what kinds of harm are relevant to their asylum claim. We tend generally to think of refugees as fleeing political persecution. Actually if you're fleeing domestic violence, and there's no state protection in your country, then you might fall within the Refugee Convention and be able to make an asylum claim, but you wouldn't necessarily know that. ${ }^{6}$

We didn't just pluck these measures out of the air. We took them from the international protocols that are already in place for women in similar circumstances. Relevant protocols include the International Protocol on Investigating Sexual Violence in Conflict. ${ }^{7}$ Do you remember when Angelina Jolie was here wandering around London with William Hague and everyone was a bit perplexed? They came up with this protocol, and it means that if you're somewhere like the Democratic Republic of Congo (DRC) or Somalia and you're harmed by sexual violence there will be an investigation. There should be a woman investigator, you should be interviewed on your own without family or children present in your interview, officials should be trained, counselling should be available and information supplied. Sound familiar? Our argument is, if that woman in the DRC can have those measures, what happens when a woman comes from the DRC to this country and goes through the asylum process? It's so obvious to us that she has the right to those same measures.

These measures are repeated in the European Directive on Victims of Crime. ${ }^{8}$ They're also reflected in CEDAW, the UN Women's Convention, where they're listed in a general recommendation. ${ }^{9}$ The issues around the rights of women, escaping violence, are referred to in the Istanbul Convention, which the UK has signed and not yet ratified. ${ }^{10}$ So as a campaign that's our rationale, we're not just

\footnotetext{
6 Supra n 3.

7 Foreign and Commonwealth Office, International Protocol on the Documentation and Investigation of Sexual Violence in Conflict. 2014. First Edition: June. Available at http://www.refworld.org/docid/ 53f2fed34.html. Accessed 10 January 2017.

${ }^{8}$ Directive 2012/29/EU of the European Parliament and of the Council of 25 October 2012. Establishing Minimum Standards on the Rights, Support and Protection of Victims of Crime.

9 United Nations, General Assembly, Convention on the Elimination of All forms of Discrimination Against Women, UNTS 1249, 18 December 1979. Entered into force 3 September 1981. http://www. ohchr.org/EN/ProfessionalInterest/Pages/CEDAW.aspx. Accessed 26 January 2017. See also CEDAW Committee. General Recommendation no 32 on the Gender Related Dimensions of Refugee Status, Asylum, Nationality and Statelessness of Women CEDAW/C/GC/32.

${ }^{10}$ Council of Europe, Convention on Preventing and Combatting Violence Against Women and Domestic Violence, CETS: No 201011 May 2011. Entered into force 1 August 2011. https://rm.coe.int/ CoERMPublicCommonSearchServices/DisplayDCTMContent?documentId=090000168046031c. Accessed 25 January 2017.
} 
saying these things would be nice, we're saying, "If a victim of crime in Europe has a right to these things, then why hasn't a woman who is claiming asylum here?"

All these measures are important because they are relevant to credibility. If you ask women who've been through the asylum process "What's the most important issue? What's the thing you're most concerned about?" They will say "credibility." It's the concern about not being believed when they claim asylum. This affects men and women. The UNHCR report, Beyond Proof, looks at the concerns about credibility assessment in Europe (UNHCR 2013). This is a European report that we were involved in developing with five European partners. The European Parliament then published our research. In the nine countries we studied, it was credibility that was at the core of refusals of women's asylum claims.

The nature of the Refugee Convention is problematic because when it was written it focused on men fleeing political persecution. As you probably know it was created in 1951 after the Second World War, the Holocaust and as the Iron curtain came down. It was mostly about straight white men coming across from Eastern Europe into the West to escape Communism. The complication is, that you can only claim persecution for one of five reasons; nationality, race, religion, political opinion or because of membership of a particular social group. It does not list gender or sexuality. But the Refugee Convention has been interpreted in a gendersensitive way. So it can take account of the issues that affect women, and gay people, but it is a really difficult process.

As well as having to show that your persecution is for one of the reasons stated in the Refugee Convention you also have to show there was no state protection in your country. If you're being harmed by the state, for example, if you are imprisoned and tortured because of your political opinions, it's really obvious the state is not protecting you. If a member of your family harms you then it's much harder to show the lack of state protection. The law may not outlaw domestic violence or if there is a law it may not be enforced. If you go to the police they may tell you to go back home. You also have to show that there isn't somewhere else in your country you could go. So if you're being persecuted by the state the chances are you can't go anywhere in your country because the police or military will find you. If it's your family that's harming you, the Home Office might say that you could live in a different area to your family. In some countries that's possible, but in many countries, where refugee women come from, you can't just go and set up home on your own and live as an individual woman as a single mother or as a widow. You would be ostracised as male protection is required in that country. This is another hurdle that affects women more than men, because women are more likely to have claims based on gender violence.

One of the things we found in our research Unsustainable was that when women were refused asylum it was always because of credibility. It was because they weren't believed. Half of the cases that were appealed had their refusal overturned because the immigration judge did believe them (Asylum Aid 2011). Then we reviewed the Home Office stats and we found that if you looked at men's and women's cases, women's cases had a disproportionate overturn on appeal. So as a woman you were more likely to have a refusal overturned on appeal than if you were man. The Home Office only actually disaggregated their statistics by sex 
because of this research, and now they do it every year and there's always this difference of about five per cent.

So then we started looking at why is it different? Why is there a different issue for men and women in terms of how they're believed? I have written about this in an edited book collection on gender and refugee law (Singer 2014). Our argument is that as a woman it's harder to get documentary evidence to prove that something has happened in the private sphere of the home and family rather than in the public sphere. You don't get a certificate for domestic violence. So you're thrown back on your oral testimony, and because of the trauma that Princess has talked about it's very hard to give a coherent narrative about what's happened to you. There may be gaps in your narrative, you don't disclose everything, and the Home Office then say, "Well it can't be true because you're saying something different now," or, "You're only saying this late and so we don't believe you."

Another problem is that the Home Office is misinterpreting the standard of proof, which in refugee claims is "reasonable likelihood". This is considered a very low test, making it easy to prove the facts. It is certainly not as high as the criminal standard of beyond reasonable doubt. It is not as high as the test in civil cases, which is the balance of probabilities. The reason for the low standard is that it is recognised that the chances of you bringing evidence with you when you're fleeing are limited. It is also because if the Home Office get the decision wrong and sends you back, then the consequences are dire.

These principles are repeated in the European Training Manual (Gyulai et al. 2015) and in a 20 min film called Falling at each Hurdle: Assessing the Credibility of Women's Asylum Claims. It expresses the different perspectives of women who've sought asylum, and it deals with the law and policy hurdles that women claiming asylum have to overcome (Asylum Aid 2015). It is aimed at lawyers and claimants.

Finally, I want to tell you the latest news, because it's hot off the press. On International Women's Day the European Parliament voted for a resolution on the situation of women refugees and asylum seekers in Europe. ${ }^{11}$ It talks about the importance of gender sensitivity and asylum policy. The resolution was written by Mary Honeyball MEP, and it went through the Women's Committee before it went to the plenary session. It recognises gendered forms of harm, and it talks about measures that would ensure women's needs are met. I think there's seven measures there, five of them I've just told you about because they're part of the Protection Gap campaign.

So this campaign, which started in the UK, has reached Europe. The member states in the European Union are now going to be encouraged to undertake the measures we have put forward. They're not absolutely expected to do it, as it's not a law. But they need to pay more consideration to these issues. And of course it gives us more power in our argument with the Home Office to say, "Look, the European Parliament think you should be doing this." In fact, what I say to the Home Office

11 European Parliament resolution of 8 March 2016. The situation of women refugees and asylum seekers in the EU (2015/2325(INI)). http://www.europarl.europa.eu/sides/getDoc.do?pubRef=-//EP//TEXT+TA +P8-TA-2016-0073+0+DOC+XML+V0//EN. Accessed 25 January 2017. 
is, "Look, the European Parliament have just said everyone should be doing this, and isn't it brilliant, because you're already ahead of them?"

[Applause]

\section{Priya Solanki, Barrister, 1 Pump Court Chambers}

Good evening. I'm Priya Solanki. I'm a barrister at 1 Pump Court Chambers. I specialise in immigration and asylum law. I work within a team of about nineteen to twenty barristers. We're a dedicated team, and we are committed to legal aid and pro-bono work. We work only for the clients, and we don't do any government work at all. I have been working in this area since 2008. I feel very passionately about it, and I think that's why I'm willing to dedicate so much time to it. I think that particularly female asylum claims have some really difficult problems that require a lot of time, and I will give you some insight into my work.

It is really useful for me to follow up from Debora; I'm going to speak about some of the challenges that are facing female asylum seekers in the tribunal system. Princess spoke about the trauma that she faced when she was going through the interview process, and unfortunately, the trauma doesn't end there. The process of seeking asylum is about making a phone call and having a very short screening interview where you are asked brief and basic questions about your claim. However, sometimes you are required to give more detail than you're able to give in a short interview. You then have a fuller asylum interview where you really are traumatised, because you're asked about everything in a great amount of detail. Sometimes you do not have the protection that you should have in place, the sort of protection that Debora described. What then happens is you are given a decision on your asylum claim, and if that's negative it usually means that your account has been found not to be credible.

It doesn't end there. You then appeal that decision and you have to go through your account again with a solicitor. This can be very painful because you are asked some very difficult questions on the points where the Home Office has disbelieved your account. You sometimes see experts and they're sometimes medical experts who look at your scarring and talk to you about your mental health. They write reports for you that supposedly support your claim. Sometimes you'll see country experts and they'll consider the credibility of your account. You'll then go before the tribunal, and you'll go through the whole experience again in front of a judge. A Home Office representative will cross-examine you asking difficult questions with a barrister and an interpreter present. So the traumatic process of claiming asylum is unfortunately a very long one. I'm going to give you some examples of challenging cases in the tribunal that have resulted in really terrible decisions for very vulnerable asylum seeking women. I want to make it clear that the tribunal system isn't all bad. There sometimes can be very good judges who make very good decisions. But there can also be bad judges, bad days, bad procedure, and bad guidelines, that lead to awful decision making for some really vulnerable women. I also want to highlight that these cases may involve women who have been tortured or have mental health problems and who are often very embarrassed. 
So case number one, I'll call the client $A A$. She was a vulnerable female asylum seeker, and her claim was based on the fact that she had been raped by the authorities in her home country. She claimed asylum and had medical evidence from Sri Lanka. After her sexual assault she'd actually been to see a private doctor, and he had written a very brief report that supported her account of sexual assault in her home country. She also had scars on her body, which supported that account. She saw a medical practitioner in the UK, and she had a strong medical report which backed up her version of events. She had a diagnosis of post-traumatic stress disorder and depression. She went through the asylum process, and then she came to the tribunal where she requested an all-female court. $A A$ had a female barrister acting for her, that was myself, a female presenting officer for the Home Office, a female interpreter but unfortunately a male judge. I spoke to the Home Office representative and she agreed that it wasn't appropriate for there to be a male judge if $A A$ wanted an all-female court. She was quite pragmatic and sensible about it and she said, "We'll agree to the issue and hopefully the judge will just agree to it as well." When we went in the judge said, "Well you're not going to ask her about the rape, are you?" And I think that the Home Office representative at that stage felt really very pressurised, and she said, "Well okay, no I won't." And then she went away, and after about ten minutes she said, "I've just been told by a senior case worker that I need to ask about all the case." Well obviously she did, she needs to be able to put her case to the client, and the client needs to be able to answer that case. Unfortunately the judge didn't even seem to be persuaded at that stage. So I again repeated the request for an all-female court, and the judge said, "Well, she's going to find it difficult with anybody, isn't she? It may not be ideal but there it is."

$A A$ started giving her evidence and within a couple of minutes she was in floods of tears. So at that stage I repeated a request for an all-female court. The judge did give her a break and she went outside, and when she came back she was still quite visibly upset. I said, "She's clearly not going to be able to give her best evidence. It may not be that she's even going to be asked about that issue in any great detail, but generally this setting is not helping her to give her best evidence." And the judge said, "Well she's going to be upset with anybody, isn't she? Let's see how we get on." She didn't cry for the rest of the hearing and she managed to get through it. When we got the decision a few weeks later it was accepted that she had been raped, but it was not accepted that she had been raped by the authorities. It wasn't really clear how the judge had been able to come to that conclusion. He'd not really given reasons for it. The evidence showed that women from her background, ethnicity and her home area were being sexually assaulted. They were victims of sexual violence by the authorities on a frequent basis, but that evidence hadn't been considered. In fact there had been a Court of Appeal case which the judge had been referred to and that supported the argument that the authorities in that country were perpetrating this type of violence against women.

We have appealed and fortunately, $A A$ was granted a fresh hearing. I blame the problems in the case on the lack of guidance for judges on all-female tribunals. The current guidance is in the "Child Vulnerable Adult and Sensitive Appellant Guidance". It says that the tribunal should "Consider any request for a single gender tribunal," but that it should "...bear in mind that sensitive issues may not be the 
subject of questions or core to the evidence." ${ }^{12}$ It goes on to say, "There is no provision in our jurisdiction for support for vulnerable adults but you may consider it appropriate to suggest attendance by such an individual to assist the appellant in giving evidence." Then finally in the same section it says, "In the final analysis it is the tribunal's decision whether specific arrangements are made, what those arrangements are and whether the hearing can proceed in their absence." 13 So effectively the guidance is saying you can look at a request for a single gender tribunal but you don't need to do it. So in those circumstances the judge could say, "Well I was perfectly right not to help that client in that way. I didn't need to make her feel comfortable. I didn't need to help her to give her best evidence because in fact my own guidance is telling me all I need to do is look at it, and I can come to the final conclusion as to what I think is best in a case." Effectively that is what the judge did. He thought it was okay for her to continue, and so that is what we did. I think that the guidance needs to be redrafted so that it is gender specific. This brings me on to the next case.

So this case highlights the lack of understanding of gender related issues in the tribunal system. I'll call this client $B$. She was a vulnerable female asylum seeker. Her husband came to the UK and claimed asylum, but his claim was rejected. She remained in her home country. Whilst she was there she was raped, sexually assaulted and detained. She came to the UK a few years later and sought asylum in her own right with her husband as a dependant on her claim. She believed that the reason she had been persecuted was because of her husband's activities when he had been in their home country. So she linked her claim to what he had done. UNHCR guidelines say that women often don't understand the reasons why they are being persecuted. $B$ may well have thought her claim was based on her husband's persecution, but actually there could have been several reasons. She came from a country where women are often raped, detained and treated in the way she described. She didn't attribute the way that she was treated to her own situation. She put it down to her husband's activity specifically.

When she claimed asylum her husband also gave evidence in support. In fact he was re-interviewed by the Home Office. When we went to the tribunal he gave evidence as well. $B$ had very strong medical evidence stating that she suffered from severe anxiety, severe depression, post-traumatic stress disorder and psychotic symptoms. She had medical evidence showing scarring that was consistent with her account. The judge found that she was completely consistent in what she was saying, but he found that her husband was inconsistent and he therefore didn't believe her. This was crazy because it's actually her asylum claim. She had very strong evidence including independent medical evidence, but her husband's account was enough for her claim to be rejected.

I didn't deal with this claim in the tribunal. It came to me at a very late stage. I think the problem was that the tribunal hadn't approached the case from a gender

\footnotetext{
12 Child, Vulnerable Adult, and Sensitive Appellant Guidance. Joint Presidential Guidance Note No 2 of 2010. 30 October 2010. https://www.judiciary.gov.uk/wp-content/uploads/2014/07/ChildWitnessGuid ance.pdf. Accessed 1 October 2016.

13 Ibid. para. 6.
} 
specific point of view. They had simply looked at whether or not the husband's political activities were sufficient to make out the claim. So they based the decision on political opinion, and didn't look at whether or not she was fleeing the persecution as a woman of her ethnicity from her home country.

She has submitted a fresh claim arguing on a gender specific basis. It means that she's going to have to go through this whole process again, and she has all of these negative findings against her to deal with now. There used to be gender specific guidance for the tribunal, but it was decided in 2010 to go backwards and to get rid of it. So now we just have the "Child and Vulnerable Appellant Guidance", which touches upon gender, but it doesn't really go into the sort of detail that we need. If we had gender specific guidance I don't think that this type of thing would have happened. I don't think either of these cases would have got to the point that they did. Maybe the Protection Gap campaign will assist.

Debora Singer: Well this actually connects us to Asylum Aid's current project, which is the Women Asylum Appeals Project. We'll be producing a report on our research, and it's looking into how women feel about what's going on in tribunals. It's scrutinizing the case files to see what is actually happening in these cases. It's also looking into the effectiveness of the current guidance on vulnerable and sensitive appellants.

Priya Solanki: The last example is the case of $\mathrm{C}$. This is an on going case that really troubles me. $\mathrm{C}$ is a victim of domestic violence in a country where it's known that there are extremely high levels of family violence. The domestic violence spanned over an 18-year period. The violence took place during an 8 year marriage and then continued following the divorce, custody proceedings and thereafter. The violence included being raped, kicked and having cigarettes put out on her body. There was also financial and emotional control and physical abuse outside a court building. Her child was intimidated and threatened at school, and on the streets. She also had a gun held to her head outside of her own home. There were gaps in the violence, but it went on for many years.

In this case the judge found that her account and chronology was completely credible. However he then went on to say that, "There is nothing," and this is me quoting, "There is nothing to suggest to the tribunal that this individual has been specifically and repeatedly targeted and that there is simply no credible evidence that any risk upon return is well-founded or indeed ever has been." I just don't know how he came to this conclusion when he accepted everything that she had said. I think that the problem in that case was he hadn't read the evidence. If he had read it then he simply could not have come to that conclusion. Alternatively, he just didn't understand the definition of persecution, which is a possibility unfortunately.

The client was unfortunate in having the wrong judge on the wrong day. Potentially he was overworked. Maybe he had too many cases or too much on personally on that day. Who knows? But whatever has happened that case has gone horribly wrong. The tribunal system has really, really failed her. The case really highlights that the challenges faced sometimes are not to do with guidance or the law but to do with individuals, and that's something that can be really very difficult 
to change. So there's lots of work to be done for this very vulnerable group of women, and I'm now going to pass you on to Zoe.

[Applause]

\section{Zoe Harper, Legal Officer, Immigration Law Practitioners' Association.}

Thank you. I'm Zoe Harper from the Immigration Law Practitioners' Association, or ILPA for short. ${ }^{14}$ ILPA is a membership organisation of around 3000 immigration law practitioners. ILPA aims to promote and improve advice and representation in immigration, asylum and nationality law, and we have an extensive programme of training and information dissemination to both lawyers and the public. Our main aim is to secure a non-racist, non-sexist, just and equitable system of immigration, refugee and nationality law. In order to achieve this we undertake research and policy work on legal issues affecting migrants including refugees and asylum seekers. We draw on the experience of our members in representing those groups. We're represented on various stakeholder and advisory groups, and regularly provide evidence to parliamentary and official inquiries. We're the agency that's leading advocacy on the current Immigration Bill ${ }^{15}$ going through Parliament.

I'm going to talk to you about the importance of access to high quality legal advice for women asylum seekers and about the government's Immigration Bill. We think the bill is a lost opportunity to deal with the real problems asylum seekers have in accessing protection and in dealing with the current refugee crisis. I would support all of the points made by the previous speakers about the difficulties that women experience in the asylum system, for example the decision making by the Home Office and the tribunal. They are all issues ILPA has highlighted in its own policy work. Our work indicates the importance of having a skilled legal representative to help women navigate this process and challenge poor decisionmaking. It's particularly true for women, because as indicated their cases are likely to be more complex because of the difficulties of applying the Refugee Convention. There are also difficulties in gathering evidence to support women's claims and developing a safe space to support disclosure of traumatic experiences. Disclosure often needs time, and the development of a relationship of trust. Lawyers can support a woman giving their account and this is helpful because in some countries where women face persecution their status is so low that they may never develop a narrative about their life, because it's not been necessary.

The general Home Office position is that you don't need a legal representative to tell the truth. However, we have seen how problematic the treatment of women in the asylum process can be, and how important it is to have a legal representative to challenge discrimination and enable the truth to be heard. There's no automatic entitlement to legal advice in the asylum process and many women cannot access it

\footnotetext{
14 See further: http://www.ilpa.org.uk/. Accessed 10 September 2016.

15 Immigration Bill 2015-16 http://services.parliament.uk/bills/2015-16/immigration.html. Accessed 25 January 2016, now the Immigration Act 2016, see https://www.gov.uk/government/news/immigrationbill-receives-royal-assent. Accessed 28 March 2017.
} 
at an early stage in their claim. It's quite common for women not to have a representative before they go for a screening interview. Increasingly the Home Office use screening interviews to decide how the case should proceed, for example whether the woman should be detained. Normally there is not enough information available at the screening interview to make these decisions. If the interviewer probes further then women should have legal advice. There is legal aid available for asylum and protection claims. So women may access legal advice and be represented by a legal adviser for their claim.

However legal aid is very restricted. Legal aid is available for asylum and protection claims, but for adults this is done on a fixed fee basis. I'm going to get a bit technical here. So here's the science bit. Under a fixed fee a legal aid lawyer is paid the same fee no matter how much work they do on a case. The fixed fee is said to be an average fee, but actually it's quite limited. The figures... generally for the first part of a case preparation for an initial decision, it is eight hours. It is not very much at all if you think about how long it takes just to explain the process to a client, to interview them and to prepare evidence and statements. There is some exceptional provision. If across the whole case from both the decision and the appeal it is more than three times the average case, more than three times the fixed fee, then you may claim for the actual work that you've done, not just the minimal fee. But you won't get paid if you only reach two and a half times. In those circumstances you lose that time, and the bill may be disallowed altogether. As a legal aid lawyer you take the risk that if you do the level of work required you may or may not get paid depending on the legal aid agency assessment of the file at the end of the process. So there's a financial risk involved for lawyers when taking a case. Just to put those figures in perspective, when I was in practice before moving to this policy role I would generally take between 20 and $30 \mathrm{~h}$ to take a statement in a trafficking case or a case involving sexual violence. Among specialist legal practitioners that's about average and quite common because of the need to take particular care in taking instructions with someone who has suffered trauma.

Other factors that have restricted the availability of legal advice have been cuts in legal aid fees. The losses that firms experience in working to a fixed fee, that only pays a certain amount for a particular case, makes it hard for firms to be financially viable. Two of the largest not-for-profit providers have closed in the last five years for these reasons. This means that the amount of legal advice available has very been much reduced. ${ }^{16}$ The recent Legal Aid Sentencing and Punishment of Offenders Act 2012, implemented in 2013, has made things a lot worse. ${ }^{17}$ This Act took many areas out of the scope of legal aid. So certain aspects of law are no longer funded by legal aid, and one of those areas is general immigration law. There are some exceptions around an exceptional funding scheme, but they are notoriously difficult to apply. Most asylum lawyers managed to survive the fixed fee scheme because they could combine their asylum practice with immigration work. The loss of the immigration work, supported by legal aid, has meant that many firms and not-for-profit organisations were no longer viable. So we've seen increased

\footnotetext{
${ }^{16}$ For details on the legal aid scheme see Ling, Pugh and Edwards (2015).

17 For a discussion of legal aid in immigration cases see York (2013).
} 
closures of quality providers, and loss of expertise. This is a general immigration concern but it does affect other groups as well. So for example the loss of general immigration advice from legal aid means that immigration advisers who might have a generalist practice may not see a person who might come because they were concerned about their irregular immigration status or concern. They are not now in a position to identify the fact that that person may have an asylum claim or may be a victim of trafficking. So the loss of general immigration advice is also a limiting factor on access to advice for asylum seekers and refugees more generally.

So we've seen advice deserts open up in parts of the country at a time when the numbers of those in need of protection are increasing following the refugee crisis. We're also seeing asylum seekers being dispersed to different areas of the country with no account taken of the availability of legal advice provision in those areas. Even those areas, such as the Liverpool/Manchester conurbation where there's traditionally been dispersal of asylum seekers the availability of advice is becoming increasingly difficult to access. This is particularly the case where women need to make fresh claims in order to rectify problems that have gone wrong in the asylum process. Priya spoke really well about this. When the asylum process goes wrong, that either leads to women facing removal to situations where they face danger, or being left in quite vulnerable positions trying to seek advice and get the evidence to put together further submissions to submit as part of a fresh claim.

The Immigration Bill introduces a raft of measures mostly targeted at general immigration, but also aimed at creating a hostile environment for people at the end of the asylum process and for people with irregular immigration status. ${ }^{18}$ In our view the government's Immigration Bill is a real distraction from and a lost opportunity to deal with the real problems. There's a need to improve the quality of decision-making, administration and accountability throughout the Home Office to tackle some of these problems. Yet civil servants are being distracted with this bill when there's a need for investment in the kinds of strategies to improve determinations in women's claims. There's a need to tackle trafficking in human beings and modern slavery. At the time of the greatest forced displacement of persons since the Second World War there's a need to ensure that borders aren't closed and that refugees are not sent away to places where they face persecution. They must be treated with dignity and respect and their needs should be met.

So as the Immigration Bill has gone through Parliament, ILPA has been pressing for amendments. These are aimed at trying to create safe and legal routes to escape persecution, because women and other asylum seekers are at risk in the journey to reach places of safety. ${ }^{19}$ Under international law you have a right to claim asylum and you have a right to seek protection from persecution. Yet a whole range of measures in domestic law criminalises and prevents people from doing this. So you can't get a visa to seek protection in the UK because there isn't a visa available to seek asylum. You're not allowed to use deception to apply for another visa to get

\footnotetext{
18 Immigration Bill 2015-16 http://services.parliament.uk/bills/2015-16/immigration.html. Accessed 25 January 2016, now the Immigration Act 2016, see https:/www.gov.uk/government/news/immigrationbill-receives-royal-assent. Accessed 28 March 2017.

19 See Immigration Law Practitioners' Association Briefings (2016) at: http://www.ilpa.org.uk/pages/ briefings.html. Accessed 10 September 2016.
} 
here, and then claim asylum because that's deception and is unlawful. It's unlawful in domestic law to take other routes to enter the UK unlawfully. So there isn't actually in domestic law a lawful way of getting protection. That's why the UK has such a small percentage of refugees compared to the situation worldwide.

One of the problems is the risk that people face in accessing safety. So many people in Calais and in other camps in France are living in very difficult situations seeking to join family members in the UK. The Dublin system that would help people who are vulnerable be reunited with family members isn't operating properly. ${ }^{20}$ A French court recently found that conditions in Calais in November were inhuman and degrading in breach of Article 3 of the European Convention on Human Rights. Even more recently a UK court found that although there were improvements in that position the situation hadn't changed. This was because the numbers of people had increased offsetting the improvements there. They found that: "the appalling and dangerous living conditions continue. The dangers include trafficking, violence, exploitation of unaccompanied children and the abuse, including rape, of women. Other sources of danger to human health include toxic white asbestos giving rise to the risk of carcinogenic disease." 21

So ILPA is pressing for amendments to try and support safe and legal migration, and there are at least three ways this could be done. People could be enabled to resettle in the UK automatically from the areas where they are at risk. So humanitarian visas could be issued to those in Syria and other countries that are in circumstances of crisis. One key measure that we're pressing for is to widen family reunion measures. In many cases there are people here in the UK who have vulnerable family members in precarious situations in camps or in countries where they're at risk. Widening the family reunion measures, that already exist would not require legislation and would enable people to join relatives in the UK. There's a benefit in that because people have family here so they would integrate quickly. These measures would avoid people trying to seek safety putting themselves at risk.

More generally it is important to recognise that people who do use routes to come to the UK and seek protection, require a protective response. We have real concerns about the government's announcements of quite hostile measures that may come down the line towards people who arrive and seek protection. This is the case even though in international law that's a proper, fair and reasonable means of seeking protection from persecution.

At the moment in Parliament there's an amendment that's been laid by Lord Dubbs, which I'm going to speak to in order to raise this issue of family reunion. The amendment is to resettle 3000 children in the UK. This doesn't seem to have much bearing on what I'm talking about in terms of family reunion. This

\footnotetext{
${ }^{20}$ Convention Determining the State Responsible for Examining Applications for Asylum lodged in one of the Member States of the European Communities (Dublin Convention). 15 June 1990. Official Journal C $254,19 / 08 / 1997$ p. 0001-0012. http://eur-lex.europa.eu/legal-content/EN/ALL/?uri=celex\% 3A41997A0819(01). Accessed 25 January 2017.

${ }^{21} R$ (On the application of ZAT, IAJ, KAM, AAM, MAT, MAJ and LAM v. Secretary of State for the Home Department JR/15401/2015; available at http://www.asylumlawdatabase.eu/en/case-law/unitedkingdom-queen-application-zat-iaj-kam-aam-mat-maj-and-lam-v-secretary-state-home. Accessed 28 March 2016.
} 
amendment, which has been proposed to ensure protection for 3000 children and which will assist children who are scattered in Europe trying to access protection. We are briefing on this because there is a separate amendment that has been discussed in committee around widening family reunion provisions in order to provide safe and legal routes for people to access safety. Through this amendment about children there's an opportunity to also talk about the wider needs of others seeking protection, and the importance of using those routes. The amendment is likely to come back to the House of Commons after Easter, and so this would be a really useful issue on which to write to MPs to raise awareness of the importance of helping people access safety, particularly in the context of the crisis and to support this amendment with a view to supporting the provision of safe and legal routes for migration. $^{22}$

So just to finish, I want to make three points. These are the importance of being able to access safety without a risky journey. This is especially relevant for women who become particularly vulnerable during these journeys. It is also important to have proper determination procedures and a compassionate, empathetic response when women seek protection in the UK. Finally it is for legal advice to be funded, and supported in order to support women through those processes. Thank you.

[Applause]

\section{Questions from the Audience}

After the presentation there were questions from the audience. Some of the questions and answers on the asylum process are summarised here.

Question 1: My question is to Priya, or to anybody who can answer. You were talking about gender specific work in tribunals. The question is, do you know and how easy is it to find out how many female judges there actually are in immigration and asylum tribunals?

Priya Solanki: I'm in the tribunals on an almost daily basis. There are a decent amount of women. It's funny. You don't always want an all-female court. Sometimes your clients really want that, and if they want that and that's what they feel comfortable with, then that is exactly what you do. But I don't always think that it's the best thing. I sometimes find that male judges are very sympathetic, and more so than some female judges.

Zoe Harper: I think I'd agree with that. It's not enough to be a woman to be gender sensitive. It is important for men and women practitioners to have training on gender sensitivity. The assumption is that just because you're a woman you understand and are going to be empathetic, but I think we've all come across Home Office decision makers and judges where that is not the case.

\footnotetext{
22 After much Parliamentary debate and negotiation with the government, Lord Dubb's amendment was accepted in part. See the statement of the Minister of State for Immigration, James Brokenshire, 21st April 2016, HCW687. https://www.parliament.uk/business/publications/written-questions-answersstatements/written-statement/Commons/2016-04-21/HCWS687/. Accessed 25 January 2017.
} 
Editor's Note: The available statistics state that $43.8 \%$ of the judges in the tribunal system are women and in the younger age band (under 40 years of age) $56 \%$ of the judges are female compared with $29 \%$ in the over 60 band (Judicial Office Statistics Bulletin 2015).

Question 2: My question is for Debora. Debora, I know you said a little while ago that in relation to your policy work with the Home Office that you would sometimes use the comparison between the way that women victims of sexual violence are treated in the UK, and the way that they are treated when they come to claim asylum. So my question is in the context of the new developments on the sexual abuse of children by the Crown Prosecution Service (CPS) on charging and credibility, have you had any traction with persuading the Home Office to adopt these higher standards in immigration cases?

Debora Singer: I think it's probably true to say our traction on that has been limited. We do keep quoting the fact that in the criminal justice system, the CPS and the police have this sense of believing victims of sexual violence. So if a woman comes and alleges rape you don't then start destroying her personality, which is what used to happen in rape cases in this country about 20 years ago. Our argument is that the Home Office should learn from the experience of the criminal justice system and of the police and the CPS. It should be realised that if you start by believing somebody you're more likely to be able to collect the evidence you need. Sure, at the end of that, you might decide, actually no, but you're not going to get that information unless that's the way you begin. We are trying to start a dialogue with Home Office and see if they can have a dialogue with, for instance, the College of Policing or the CPS.

Princess Chine Onyeukwu: A particular problem faced by women in asylum interviews is being asked repeatedly the same question. It is very traumatising when you are asked a question that requires a straightforward answer, and you give that answer. Then the person keeps asking you the same question in different ways. It's very irritating, to say the least. It may traumatise you, and make you feel really low. It's so sad when you are trying to tell your story about why you left every good thing that you had in your life. You have left your loved ones and the things that made you happy to flee to an unknown place. What I discovered from women I have spoken to is that they just withdraw. This doesn't help their claim and the interviewer is likely to hold that their story is inconsistent and that they are not telling the truth.

Question 3: I would just like to ask really quickly, why are the people who work at the Home Office this cold? Are there really bad policy reasons why they are trained like that?

Zoe Harper: It is a really big question. I don't think there's a single answer. I think there's a lack of implementation of policy and guidance around gender issues and asylum claims. Through efforts from ourselves, Asylum Aid and other agencies, we've inputted into guidance, and often the guidance can be really good. It's just not implemented in practice, and the Home Office is quite a large monolith with real 
difficulties around management and administration. We heard in the press, just this week, of people who are making decisions on asylum claims being in student gap years. So they are taking people with quite limited training and input to make life or death decisions.

There's also, I think, a wider reason. We talk a lot about a culture of disbelief. There is this automatic disbelief of women in the asylum process and other asylum seekers. We've really tried to unpack how this happens. One of our running theories is around becoming case hardened and the lack of support for Home Office officials and judges around coping with the level of trauma and abuse that they're faced with when interviewing asylum applicants. So it is far easier to not believe that this awful horrific thing has happened than to actually engage with the kinds of horrors such as violence towards women and other forms of torture.

There are also systemic issues. At the moment we have been advocating quite strongly with the Home Office. They went through a period of complete chaos in the last couple of years when they moved back into the Home Office from the Border Agency, where they were managed in a slightly separate wing. They were so behind on their targets, that they'd have one person interview an asylum seeker, and then have somebody completely different make the decision in an office on the papers. They have never met this person but they work purely from the written notes of that interview. It is really poor practice, which we've tried to challenge.

Also the narrative around deterring asylum has been a political football for a long time. The knee jerk reaction by the authorities is to become more restrictive, but the human rights abuses in the world haven't gone away. People are still in need of protection from horrific violations of their human rights. So the language of deterrence is really unhelpful. It also affects the culture of the Home Office in taking that approach when dealing with people on a more human level. Those are my theories.

Princess Chine Onyeukwu: It would be wrong for me to say, 'Oh all of them are horrible'. No, that's not it. I encountered some very fine officers at the Home Office; not that they did something that was out of the ordinary. That's what every single one of them should be doing; they should just be pleasant and treat you with respect. Interviewers can do their job strictly and professionally, but with a human face. It makes all the difference. Personally I think they need to go through some kind of training. But I also think it has a lot to do with how society perceives asylum seekers. The press are not helping matters because of the way they portray this group of people. The Home Office, I believe, at some level, were trained to scare people. They believe that when you scare people, the truth will start flying out. It's not true. If you are telling a genuine story you may forget the date or when it happened, but you still remember the story. If you are woken up from sleep you will still remember the story. So I think there has to be some kind of change of attitude. You can still be nice and do your work. You can still reject a claim for whatever reason. But you don't have to make people feel terrible, horrible, or demean them so that they break down and weep. You don't have to do that to be able to get the truth. People will tell the whole truth or disclose everything when they are more relaxed. 
Harriet Samuels: After four great presentations, and great questions, I think it's time to wrap up. I wanted to make a few quick observations about some of the things covered by our speakers and the audience. Listening to the presentations reinforces the need for a gendered perspective. We can see the importance of the disaggregated statistics based on sex revealing the credibility gap and the need for judges, lawyers and immigration officers to have training and be sensitive to gender issues.

It is important to take a feminist approach that involves looking at the practicalities and what happens on the ground. So the need for childcare during asylum interviews falls into that category. As somebody who spends a lot of time working on public law and human rights it is notable how often the speakers have mentioned their reliance on the various human rights resolutions, treaties, declarations and codes of practice. They create norms and principles that help us hold governments and public authorities to account.

We have also heard how important it is to listen to people telling their stories. I'm very grateful to Princess for sharing some of her experiences with us, giving us a personal perspective. But we also need to think about some of the broader issues as well. For example, Princess, when she was talking about what it means to be a refugee, mentioned that perhaps you ought to be able to be a refugee if you're fleeing poverty as well, which I know opens up huge questions that we can't possibly answer now, but I think that it something for us to be thinking about. On that note, I'd like to thank our speakers again for their wonderful contributions and for giving up their time.

\section{References}

Asylum Aid. 2011. Unsustainable: The quality of initial decision making in women's asylum claims. http://www.asylumaid.org.uk/wpcontent/uploads/2013/02/unsustainableweb.pdf. Accessed 10 Sept 2016.

Asylum Aid. 2015. Falling at each hurdle: Assessing the credibility of women's asylum claims. http:// www.asylumaid.org.uk/new-video-on-credibility-assessments-in-womens-asylum-claims/. Accessed 10 Sept 2016.

Barnden, Tim. 2013. Family reunification requirements: Barrier or facilitator to integration. Journal of Immigration, Asylum and Nationality Law 27 (2): 174-181.

BBC. 2015. Migrant crisis: Photo of drowned boy sparks outcry. BBC News, 3 September. http://www. bbc.co.uk/news/world-europe-34133210. Accessed 10 Sept 2016.

Dennison, James, and Matthew Goodwin. 2015. Immigration, issue ownership and the rise of UKIP. Parliamentary Affairs 68: 168-187.

Edwards, Alice. 2010. Transitioning gender: Feminist engagement with international refugee law 1950-2010. Refugee Survey Quarterly 29 (2): 21-45.

Gyulai, Gabor, Debora Singer, S. Chelvan, and Zoe Given-Wilson. 2015. Credibility assessment in asylum procedures: A multidisciplinary training manual, Volume 2, Hungarian Helsinki Committee. http://helsinki.hu/wp-content/uploads/CREDO-training-manual-2nd-volume-online-final.pdf. Accessed 25 Jan 2017.

Judicial Office. 2015. Judicial diversity statistics. Judicial Office Statistics Bulletin 10.

Ling, Vicky, Simon Pugh, and Anthony Edwards. 2015. Legal aid handbook 2015/16. London: Legal Action Group. 
Singer, Debora. 2014. Falling at each hurdle: Assessing the credibility of women's asylum claims in Europe. In Gender in refugee law: From the margins to the centre, ed. Efrat Arbel, Catherine Dauvergne, and Jenni Millbank, 73-115. London: Routledge.

Townsend, Mark. 2015. Yarl's Wood: UN Special Rapporteur to censure UK government. The Guardian, 3 January. https://www.theguardian.com/uk-news/2015/jan/03/yarls-wood-un-special-rapporteurcensure. Accessed 25 Jan 2017.

UNHCR. 2002. Guidelines on International Protection: Gender-related persecution within the context of Article 1A(2) of the 1951 Convention and/or its 1967 Protocol relating to the Status of Refugees. HCR/GIP/02/01 7 May. http://www.unhcr.org/uk/publications/legal/3d58ddef4/guidelines-inter national-protection-1-gender-related-persecution-context.html. Accessed 10 Sept 2016.

UNHCR. 2002. Guidelines on International Protection: "Membership of a particular social group" within the context of Article 1A(2) of the 1951 Convention and/or its 1967 Protocol relating to the Status of Refugees. HCR/GIP/02/02 7 May. http://www.unhcr.org/uk/publications/legal/3d58de2da/ guidelines-international-protection-2-membership-particular-social-group.html. Accessed $10 \mathrm{Sept}$ 2016.

UNHCR. 2008. UNHCR Handbook for the protection of women and girls. http://www.unhcr.org/uk/ protection/women/47cfa9fe2/unhcr-handbook-protection-women-girls-first-edition-complete-publica tion.html. Accessed 10 Sept 2016.

UNHCR. 2013. Beyond proof: Credibility assessment in EU asylum systems. Full Report. http://www. refworld.org/docid/519b1fb54.html. Accessed 10 Sept 2016.

UNHCR. 2016. Europe situation. http://www.unhcr.org/uk/europe-emergency.html. Accessed 1 Oct 2016.

Women for Refugee Women. 2015. I am human: Refugee women's experience of detention in the UK. http://www.refugeewomen.co.uk/2016/wp-content/uploads/2016/02/WRW_IamHuman_report-forweb.pdf. Accessed 10 Sept 2016.

York, Sheona. 2013. The end of legal aid in immigration: A barrier to justice for migrants and a decline in the rule of law. Journal of Immigration, Asylum and Nationality Law 27 (2): 97-194. 